\title{
Relationship between VRTN gene polymorphism and growth, slaughter and meat quality traits in three polish pig breeds
}

\section{Relação entre o políforfismo do gene VRTN e as características de crescimento, abate e carne de qualidade em três raças polidas}

\author{
Daniel Polasik ${ }^{1 *}$, Mirosław Tyra², Magdalena Szyndler-Nędza², Agnieszka Korpal ${ }^{1}$, \\ Katarzyna Woźniak-Męch'1, Arkadiusz Terman'
}

${ }^{1}$ Westpomeranian University of Technology Szczecin, Department of Genetics and Animal Breeding, Szczecin, Poland

${ }^{2}$ National Research Institute of Animal Production, Department of Animal Genetics and Breeding, Balice, Poland

*Corresponding author: daniel.polasik@zut.edu.pl

Received in September 10, 2018 and approved in October 30, 2018

\begin{abstract}
Earlier studies have shown that insertion/deletion polymorphism (g.20311_20312ins291) in vertnin (VRTN) gene is associated with number of vertebrate in pigs. Because vertebral number determines the size of important meat cuts and influences carcass conformation, the aim of this study was to estimate the relationship between VRTN gene polymorphism and growth, slaughter and pork quality traits including texture parameters. Investigations were carried out on 526 pigs represented three breeds: Polish Landrace, Polish Large White and Puławska. VRTN gene polymorphism was determined by PCR methodology. Association study was performed for each breed separately. It was demonstrated that the analyzed polymorphism had significant influence on several economically important porcine traits. Among growth traits VRTN genotypes were associated with test and lifetime daily gains, number of days on test $(\mathrm{p} \leq 0.05)$ and age of slaughter $(p \leq 0.01, p \leq 0.05)$. For carcass parameters, relationships were noticed for carcass yield ( $p \leq 0.01)$, weight of loin and its area, average backfat thickness and weight of primary cuts ( $\leq \leq 0.05)$. Taking into consideration meat quality, VRTN polymorphism influenced intramuscular fat content, meat colour (yellowness) and pH24 ( $\mathrm{p} \leq 0.05$ ). For texture parameters, it was correlated with toughness, cohesiveness, chewiness $(p \leq 0.01, p \leq 0.05)$ and firmness ( $\leq \leq 0.05$ ) measured in $M$. longissimus dorsi and $M$. semimembranosus. Only intramuscular fat content, chewiness of ham, carcass yield and cohesiveness of loin showed unequivocal tendency. In case of the first trait, each breed Wt/Wt genotype was associated with its highest values ( $p \leq 0.05$ ), while the second and third traits, $Q / Q$ genotype was correlated with its lowest values ( $p \leq 0.01$, $p \leq 0.05)$. Highest loin cohesiveness was observed in animals with $W t / Q$ genotype $(p \leq 0.01, p \leq 0.05)$.
\end{abstract}

Index terms: Swine meat; indel; association.

\section{RESUMO}

Estudos anteriores mostraram que o polimorfismo de inserção/deleção (g.20311_20312ins291) no gene da vertnina (VRTN) está associado ao número de vertebrados em porcos. Como o número vertebral determina o tamanho de importantes cortes de carne e influencia a conformação da carcaça, o objetivo deste estudo foi estimar a relação entre o polimorfismo do gene VRTN e as características de crescimento, abate e qualidade da carne suína, incluindo parâmetros de textura. 526 suinos representados por três raças: Landrace polonês, polonês Large White e Puławska foram estudados. O polimorfismo do gene VRTN foi determinado pela metodologia de PCR. O estudo de grupo foi realizado para cada turno de pesquisa e para todas as raças unidas. Foi demonstrado que o polimorfismo teve um impacto significativo em vários caracteres suínos economicamente importantes. Entre as características de crescimento, os genótipos da VRTN foram associados ao teste e ao longo da vida, o número de dias sem teste $(p \leq 0,05)$ e a idade de abate $(p \leq 0,01, p \leq 0,05)$. Nos parâmetros de carcaça, foram observadas relações para rendimento de carcaça $(p<0,01)$, peso do lombo e sua área, espessura média de peso e peso dos cortes primários $(p \leq 0,05)$. Levando em consideração as características de qualidade da carne, o polimorfismo da VRTN influenciou o conteúdo de gordura intramuscular, cor da carne e pH24 $(\mathrm{p} \leq 0,05)$. Para os parâmetros de textura, houve correlação com sensibilidade, coesividade, mastigabilidade $(p \leq 0,01, p \leq 0,05)$ e firmeza $(p \leq 0,05)$ medidas em $M$. longissimus dorsi e $M$. semimembranoso. Apenas o teor de gordura intramuscular, mastigabilidade do fiambre, rendimento de carcaça e coesão do lombo selecionada,. No caso da primeira característica, em cada raça e grupo unido, o genótipo $W t / W t$ foi associado com seus maiores valores $(p \leq 0,05)$, enquanto que no caso da segunda e terceira característica, o genótipo $Q / Q$ foi correlacionado com seus filhos valores ( $p \leq 0,01, p \leq 0,05)$. A maior coesão de lombo foi observada nos animais genotípicos com $W t / Q(p \leq 0,01, p \leq 0,05)$

Termos para indexação: Carne de porco; indel; associação. 


\section{INTRODUCTION}

The number of vertebrae in pigs varies considerably. Vertnin (VRTN) is involved in the variation of vertebral number in pigs. The number of vertebrate is a phenotypic trait with high heritability estimates of 0.60 to 0.62 in domestic pigs (Fredeen; Newman, 1962). The porcine vertebrae consist of morphologically differentiated formulae: cervical, thoracic, lumbar, sacral and caudal vertebrae. The numbers of cervical and sacral vertebrae are always fixed at 7 and 4, respectively, except for rare cases in pigs as in other mammals while the number of thoracic and lumbar vertebrae varies considerably (Berge, 1948). Wild boars have 19 vertebrae, whereas European commercial breeds have 21-23. Vertebral number is an important trait in pig production because it directly determines the size of important meat cuts such as the loin and also has an overall effect on carcass conformation (Fan et al., 2013; Burgos et al., 2015). The discovery of the genes responsible for the numbers of vertebrae would facilitate the improvement of carcass and production traits that are related to the number of vertebrae, by the use of a simple and unambiguous selection process with a DNA marker (Nakano et al., 2015). Therefore, study is required to evaluate the effect of VRTN gene polymorphism on production traits and other important traits related to the number of vertebrae in different pig populations

Porcine VRTN gene is localized on chromosome 7 - SSc7 (NCBI, Gene ID: 100157734). A 291 bp short interspersed nuclear element (SINE) insertion in the VRTN gene was shown to affect vertebral number and several production traits. $Q$ allele (with insertion) increases vertebral number, however $W t$ allele (wild type, without insertion) decreases its value. SINEs are non-autonomous, noncoding transposable elements (TEs) that are 50-500 bp long. The internal regions of SINEs originate from tRNA and remain highly conserved, suggesting positive pressure to preserve structure and function of SINEs (Sun et al., 2006).

This study aimed to estimate relationship between VRTN gene polymorphism and meat production with other economically important traits in 3 different Polish pig breeds - Polish Landrace, Polish Large White, Puławska. Gilts of first two breeds are designated for mothers in the fatteners production. They are characterized by many, healthy litters and high milk production, however late maturity. These pigs are well adapted to environmental conditions in Poland and classified to meat type (high carcass lean meat content). Polish Landrace and Polish Landrace breeds are free from $T$ allele of $R Y R 1$ gene (ryanodine receptor 1), through its elimination in breeding programs. Puławska breed, however is under the Program of Farm Animals Genetic Resources Conservation and classified in-between type: fat-meat and meat. Sows are characterized by good maternity traits, high milk production and early maturity. This breed is very well adopted to environmental conditions in Poland, resistant to diseases and long-living (Polish Pig Breeders and Producers Association „POLSUS”).

\section{MATERIAL AND METHODS}

\section{Animals}

The study utilized 526 sows from three breeds: Polish Landrace $(n=269)$, Polish Large White $(n=189)$, Puławska $(n=68)$. Polish Landrace pigs represent the offspring of 158 sows and 57 boars, Polish Large White 123 sows and 34 boars, whereas Puławska - 42 sows and 18 sows. Animals were maintained in Pig Tests Stations (National Research Institute of Animal Production) located in Pawłowice, Chorzelów and Mełno (Poland). Conditions in farms were as follows: temperature $-18-20^{\circ} \mathrm{C}$, humidity - 60-70\%, lighting - 45lux, $\mathrm{NH}_{3}-3 \mathrm{ppm}, \mathrm{CO}_{2}-0,1 \%, \mathrm{H}_{2} \mathrm{~S}$ $-0,0 \mathrm{ppm}$. Feeding and housing conditions were consistent for all animals. Pigs were introduced into stations at age 12 weeks and weighed approximately $30 \mathrm{~kg}$. They were fed ad libitum until they reached $100( \pm 2.5) \mathrm{kg}$ by use of 2 mixtures - mixture I (30-80kg) and mixture II (80-100kg). Mixtures I contains: barley, wheat, wheat bran, post-extraction soya meal, grain distillers, calcium carbonate, post-extraction sunflower meal (without husk), vegetable oils and fats, animal fat (poultry, pigs), sodium chloride (minimal metabolisable energy - $3223.28 \mathrm{kcal} /$ $\mathrm{kg}$, total protein $-17-19 \%$, minimal digestible protein $13.9 \%$, crude fat $-3-7 \%$, crude fibre - 2.5-3.5\%). Mixtures II was composed of: barley, wheat, wheat bran, corn, post-extraction soya meal, rapeseed expeller, sunflower seed expeller, calcium carbonate, animal fat (poultry, pigs), sodium chloride, sodium bicarbonate (minimal metabolisable energy - $3104.02 \mathrm{kcal} / \mathrm{kg}$, total protein $16-18 \%$, minimal digestible protein - $12.8 \%$, crude fat - 2-6\%, crude fibre - 3-5\%). Pigs were slaughtered by exsanguination after stunning with high-voltage electric tongs. Samples were collected from $m$. longissimus lumborum and $m$. semimembranosus for further analysis.

\section{VRTN gene polymorphism}

Genomic DNA was extracted from tissue using ReliaPrep $^{\mathrm{TM}}$ gDNA Tissue Miniprep System (Promega, USA) and Genomic Mini (A\&A Biotechnology, Poland). The genotypes of VRTN gene (g.20311_20312ins291) 
were determined using the polymerase chain reaction (PCR) methodology. Following primer sequences as described by Mikawa et al. (2011) were applied in PCR: forward 5'- GGC AGG GAA GGT GTT TGT TA - 3', reverse 5'- GAC TGG CCT CTG TCC CTT G - 3'. Each PCR reaction was performed in T3 Thermocycler (Biometra, Germany) in a total volume of $15 \mu$ l containing: $6 \mu 1$ of 2xPCR Mix (A\&A Biotechnology, Poland), $1 \mu 1$ of each primer (Genomed, Poland), $6 \mu \mathrm{L}$ of PCR grade water and $1 \mu 1$ of DNA $(20 \mu \mathrm{g} / \mu \mathrm{l})$. Thermal conditions were as follows: $94^{\circ} \mathrm{C}$ for $10 \mathrm{~min}$, followed by 29 cycles of $94^{\circ} \mathrm{C}$ for $30 \mathrm{~s}, 55^{\circ} \mathrm{C}$ for $30 \mathrm{~s}$ and $72{ }^{\circ} \mathrm{C}$ for $30 \mathrm{~s}$, followed by a final extension step at $72{ }^{\circ} \mathrm{C}$ for $5 \mathrm{~min}$. Amplified fragments were separated in $1.5 \%$ agarose gels with ethidium bromide in $1 \times$ TBE buffer at a constant voltage of $50 \mathrm{~mA}$. After electrophoresis gels were visualized in UV light and recorded by use transilluminator (Vilber Lourmat, France). $Q$ allele was determined based on presence of band with $411 \mathrm{bp}$ length, however $W t$ allele with $120 \mathrm{bp}$.

\section{Measured traits}

During maintaining in Pig Tests Stations following growth traits were estimated in each pig: test daily gain $(\mathrm{g})$, lifetime daily gain $(\mathrm{g})$, feed conversion ratio $(\mathrm{kg} / \mathrm{kg}$ gain), daily feed intake (kg), age at slaughter (days) and number of days on test (days).

Carcass yield (\%), weights of loin and ham without bone and skin $(\mathrm{kg})$, average backfat thickness $(\mathrm{cm})$, loin eye width $(\mathrm{cm})$, length $(\mathrm{cm})$ and area $\left(\mathrm{cm}^{2}\right)$, lean meat percentage $(\%)$ and weight of primary cuts $(\mathrm{kg})$ were measured during carcass dissection. The area of the loin cross-section was measured on the basis of the contour made on the cephalic plane, after cutting the tenderloin between the last thoracic vertebra and the first lumbar vertebra. Average backfat thickness was calculated from 5 measurement points: at the thickest point over the shoulder; on the back above the joint between the last thoracic and first lumbar vertebrae; at three points over the loin: above the rostral edge (loin I), above the middle (loin II) and above the caudal edge (loin III) of gluteal muscle cross-section; as described by Tyra and Żak (2012).

The following meat quality traits were measured: intramuscular fat content (IMF), meat colour, $\mathrm{pH}$ and water holding capacity (WHC). Samples for IMF content determination were taken from the middle cross sectional area of $m$. longissimus dorsi behind the last rib. Analysis was performed in thawed muscle homogenates by use Gerhardt SOX 406 (Oczkowicz et al., 2012). The pH was estimated $45 \mathrm{~min}(\mathrm{pH} 45)$ and $24 \mathrm{~h}(\mathrm{pH} 24)$ after slaughter in $m$. longissimus dorsi (last rib) and $m$. semimembranosus by use $\mathrm{pH}-\mathrm{Star}$ (Matthäus, Germany). Meat colour parameters of loin ( $\mathrm{L}^{*}$ - lightness, $\mathrm{a}^{*}$ - redness, $\mathrm{b}^{*}$ - yellowness) were determined using CR-310 Chroma Meter (Minolta Konica, Japan). To estimate WHC Grau-Hamm method was applied (Hamm, 1986). Firmness and toughness were determined by use the Warner-Bratzler Shear Force WBS analyses on raw (r) and cooked samples of $m$. longissimus lumborum and $m$. semimembranosus. For Warner-Bratzler Shear Force analysis, slices of muscle with diameter $3.5 \mathrm{~cm}$ and weight approx. $200 \mathrm{~g}$ were placed into polyethylene bag and heated in water bath to reach $80^{\circ} \mathrm{C}$. Then samples were chilled at $4{ }^{\circ} \mathrm{C}$ for $24 \mathrm{~h}$. Two cores with diameter $15 \mathrm{~mm}$, representing each sample were taken from the muscle slice parallel to the direction of muscle and sheared by use WB triangular blade $(4.5 \mathrm{~mm} / \mathrm{s})$ on TA.XT plus Texture Analyser (Stable Micro Systems, UK). Following texture profile parameters (TPA) were determined for both muscles: hardness, springiness, cohesiveness, chewiness and resilience. For TPA estimation double compression procedure was applied (cylinder SMS P/25, base diameter $50 \mathrm{~mm}$ ). All parameters were calculated according to the procedure given by Ropka-Molik et al. (2014).

\section{Statistical analysis}

All analyzed traits were assessed in a fixed model using the least squares method of the GLM (General Linear Model) procedure in the SAS software (Ver. 8.02). Primary statistical analysis included year of slaughter, sire effect and pig testing stations but their effects were not significant, therefore they were not included in the final model used in association study. The model was as follows:

$\mathrm{Y}_{\mathrm{ijklmn}}=\mu+\mathrm{b}_{\mathrm{i}}+\mathrm{g}_{\mathrm{j}}+(\mathrm{bg})_{\mathrm{ij}}+\mathrm{s}_{\mathrm{k}}+\mathrm{sy}_{1}+\mathrm{st}_{\mathrm{m}}+\beta \mathrm{SW}_{\mathrm{n}}+\mathrm{e}_{\mathrm{ijklmn}}$

where: $Y_{\mathrm{ijklmn}}$ - estimated trait; $\mu$ - the overall mean of the trait; $b_{i}$ - the fixed effect of $i$ breed; $g_{j}$ - the fixed effect of $\mathrm{j}$ genotype of VRTN gene; $(\mathrm{bg})_{\mathrm{ij}}$ - interaction between $i$ breed and $j$ genotype (when significant); $s_{k}$ - the fixed effect of $\mathrm{k}$ sire; $\mathrm{sy}_{1}$ - the fixed effect of 1 year of slaughter; $\mathrm{stm}$ - the fixed effect of $\mathrm{m}$ station; $\beta S W_{n}$ - linear effect of slaughter weight as covariate (for slaughter traits only); $\mathrm{e}_{\mathrm{ijklmn}}$ - random residual error.

\section{RESULTS AND DISCUSSION}

In the analyzed breeds of pigs all genotypes and alleles of VRTN gene were present. $Q / Q$ genotype was identified based on $120 \mathrm{bp}$ amplicon size, $W t / Q$, on $411 \mathrm{bp}$ and $120 \mathrm{bp}$, however $W t / W t$ on $411 \mathrm{bp}$ (Figure 1). 


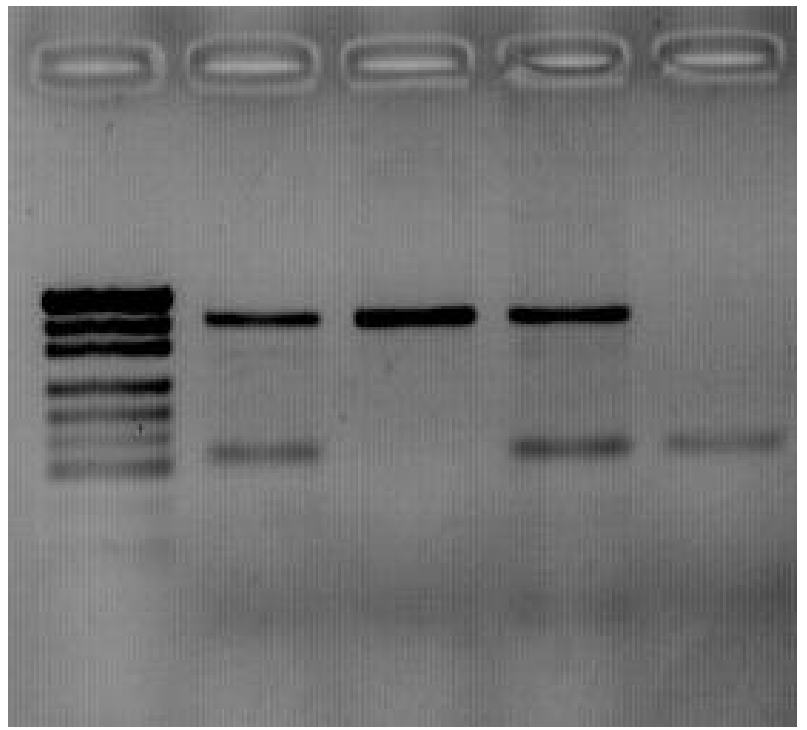

Figure 1: Electrophoresis of PCR amplicons in $1.5 \%$ agarose gel. Lanes: 1 - pUC19 DNA/Mspl (Hpall) marker; 2, 4 - Wt/Q genotype; 3 - Q/Q genotype; 5 - Wt/Wt genotype.

Table 1 shows the allelic and genotypic frequencies for the VRTN polymorphisms. The allelic and genotypic frequencies of VRTN changed depending on the breeds. The most frequently observed allele in Polish Landrace and Polish Large White breeds was $Q$ allele, as opposed to the Puławska breed where the most common allele was Wt. First two breeds are most popular in Poland and belong to meat type. Puławska, however is native breed, under protection program that represents fat-meat type. It is characterized by longevity, diseases resistance and very good adaptation to environmental conditions. Similar $Q$ allele frequency as in Polish Landrace (0.66) observed Fontanesi et al. (2014) in Italian Landrace (0.74), whereas in Italian Large White its frequency $(0.36)$ was much lower in relation to Polish Large White (0.52). They also found tendency that in five local Italian breeds $Q$ allele is less frequent (0.05-0.48), likewise in Puławska breed (0.45). Similarly, $Q$ allele was rarely in sixteen native Chinese breeds $(0.00-0.29)$ and more frequent in western Breeds - Duroc, Large White and Landrace (0.54-0.71) (Fan et al., 2013). Interestingly, Yang et al. (2016) proposed the hypothesis, assuming that the VRTN Q-type haplotype, containing $Q$ allele, was originated from Chinese pigs and have been introgressed into European breeds. Next, the Q haplotype could have been selected for pork production, leading to higher frequencies of the Q haplotype in European commercial breeds compared to Chinese indigenous pigs.
The present study showed a significant association exists between the identified polymorphisms in VRTN gene and growth, carcass and meat quality traits. The analyses performed showed the influence of breed on the majority of investigated traits. Thus, the analysis of polymorphism association with traits was performed separately for each breed.

Association between VRTN genotypes and growth traits are presented in Table 2. In Polish Landrace, Polish Large White $Q / Q$ genotype was correlated with highest values of test daily gain $(\mathrm{p} \leq 0.05)$. In case of Puławska breed we noticed significant lower test daily gains and opposed trend, because highest gains were characterized for $W t / W t$ genotype $(\mathrm{p} \leq 0.05)$. Similar tendency was observed for lifetime daily gain, but statistically confirmed only in Polish Landrace and Puławska ( $\mathrm{x} \leq 0.05$ ). In the years 2010-2012 Babicz et al. (2014) analyzed changes in the profitability of pig production of Polish Landrace and Puławska breeds. They also found that Polish Landrace pigs grew faster than Puławska which was translated into longer fattening. When take into consideration age of slaughter and number of days on test in our study, the same relationship is visible. Puławska breed is characterized by highest values of these traits, opposed to Polish Landrace and Polish Large White. Association of age of slaughter and number of days on test with VRTN genotypes was also noticed and was reverse among breeds in relation to test daily gain and lifetime daily gain. In Puławska breed, $Q / Q$ genotype was connected with their highest parameters $(\mathrm{p} \leq 0.05)$, whereas in other two breeds - $W t / W t$, but statistically confirmed only in Polish Large White $(\mathrm{p} \leq 0.05)$. Among growth traits analyzed by other authors in relation to VRTN polymorphism, there were only average daily gain and feed gain ratio. In two groups of Duroc pigs and one Italian Large White, VRTN variants, were not related with first trait. In Italian Large White, however they affect feed gain ratio random residuals (RR) $(\mathrm{p} \leq 0.05)$, but it was not confirmed using estimated breeding value (EBV) (Hirose et al., 2013; Fontanesi et al., 2014; Nakano et al., 2015).

Table 3 presents the analysis between VRTN genotypes and carcass traits. Studied polymorphism showed a significant correlation the majority of analyzed traits: carcass yield, weight of loin without backfat and skin, average backfat thickness from 5 measurements, loin eye width, loin eye area and weight of primary cuts. We found that all pigs with $Q / Q$ genotypes are characterized by lowest carcass yield in relation to $W t / Q$ and $W t / W t$. These differences were confirmed statistically in Polish Landrace $(p \leq 0.01)$, whereas in other 2 breeds were not significant. In case of average backfat thickness from 5 measurements we noticed reverse tendency between 
different pig breeds types. In meat type pigs, values of this parameter were highest for $W t / W t$ genotype $(\mathrm{p} \leq 0.05$ and $\mathrm{p} \leq 0.01$ ), however in fat-type - Puławska breed for $Q / Q(\mathrm{p} \leq 0.01)$. An analysis of $V R T N$ polymorphism in Erhualian, White Duroc $\times$ Erhualian $\mathrm{F}_{2}$ population, Duroc and Landrace pigs showed that it is not correlated with backfat thickness (Yang et al., 2016). Lack of association with this trait was also observed in Italian Large White and Duroc breeds (Fontanesi et al., 2014; Nakano et al., 2015). These discrepancies may results from genetic differences between analyzed populations. Association of VRTN genotypes with loin eye area and weight of primary cuts was noticed in Puławska pigs, whereas loin eye width only in Puławska. In all cases $W t / W t$ genotype was favorable for these traits $(p \leq 0.01$ and $p \leq 0.05)$. On the other hand, relationship with weight of loin without backfat and skin was confirmed statistically ( $\mathrm{p} \leq 0.05)$ only in Polish Landrace with $W t / W t$ genotype being positive for this trait. Fontanesi et al. (2014) proved that $Q$ allele was associated with a lower ham weight, confirming indirectly, the negative correlation reported by other studies between vertebral number and this trait. Our research also indicates this phenomenon that individuals with the $Q / Q$ genotype have a lower weight of ham as evidenced by the weight of ham without backfat and skin in Polish Large White Puławska, however it was not confirmed statistically.

Table 1: Genotype and allele frequencies calculated for the VRTN polymorphism (g.20311_20312ins291).

\begin{tabular}{|c|c|c|c|c|c|c|}
\hline \multirow{2}{*}{ Breed } & \multirow{2}{*}{$\mathrm{n}$} & \multicolumn{3}{|c|}{ Genotype } & \multicolumn{2}{|c|}{ Allele } \\
\hline & & $W t / W t$ & $W t / Q$ & $Q / Q$ & $W t$ & $Q$ \\
\hline Polish Landrace & 269 & $\begin{array}{l}0.14 \\
(37)\end{array}$ & $\begin{array}{c}0.40 \\
(109)\end{array}$ & $\begin{array}{c}0.46 \\
(123)\end{array}$ & 0.34 & 0.66 \\
\hline Polish Large White & 189 & $\begin{array}{l}0.21 \\
(39)\end{array}$ & $\begin{array}{c}0.53 \\
(100)\end{array}$ & $\begin{array}{l}0.26 \\
(50)\end{array}$ & 0.48 & 0.52 \\
\hline Puławska & 68 & $\begin{array}{l}0.22 \\
(15)\end{array}$ & $\begin{array}{l}0.65 \\
(44)\end{array}$ & $\begin{array}{c}0.13 \\
(9)\end{array}$ & 0.55 & 0.45 \\
\hline
\end{tabular}

$\mathrm{n}$ - the number of animals with given genotype.

Table 2: Association between VRTN polymorphism (g.20311_20312ins291) and growth traits in different pig breeds analyzed (LSM $\pm \mathrm{SE})$.

\begin{tabular}{|c|c|c|c|c|}
\hline Trait & Genotype & $\begin{array}{l}\text { Polish Landrace } \\
\quad(n=269)\end{array}$ & $\begin{array}{l}\text { Polish Large White } \\
\qquad(n=189)\end{array}$ & $\begin{array}{l}\text { Puławska } \\
(n=68)\end{array}$ \\
\hline Test daily gain (g) & $\begin{array}{c}Q / Q \\
W t / Q \\
W t / W t\end{array}$ & $\begin{array}{l}921 \pm 25.8 a b \\
912 \pm 25.7 a \\
916 \pm 26.0 b\end{array}$ & $\begin{array}{l}911 \pm 19.86 a b \\
883 \pm 17.07 a \\
890 \pm 21.9 b\end{array}$ & $\begin{array}{l}777 \pm 24.5 \mathrm{a} \\
816 \pm 13.31 \mathrm{~b} \\
836 \pm 20.79 \mathrm{ab}\end{array}$ \\
\hline Lifetime daily gain (g) & $\begin{array}{c}Q / Q \\
W t / Q \\
W t / W t\end{array}$ & $\begin{array}{l}621 \pm 18.76 \\
620 \pm 18.67 \\
612 \pm 19.35\end{array}$ & $\begin{array}{l}595 \pm 9.622 a \\
586 \pm 8.271 \\
583 \pm 10.64 a\end{array}$ & $\begin{array}{l}531 \pm 18.35 a \\
562 \pm 9.967 \\
578 \pm 15.56 a\end{array}$ \\
\hline $\begin{array}{l}\text { Feed conversion ( } \mathrm{kg} / \mathrm{kg} \\
\text { gain) }\end{array}$ & $\begin{array}{c}Q / Q \\
W t / Q \\
W t / W t\end{array}$ & $\begin{array}{l}2.649 \pm 0.068 \\
2.638 \pm 0.067 \\
2.646 \pm 0.070\end{array}$ & $\begin{array}{l}2.675 \pm 0.040 \\
2.695 \pm 0.034 \\
2.702 \pm 0.044\end{array}$ & $\begin{array}{l}2.884 \pm 0.063 \\
2.759 \pm 0.034 \\
2.775 \pm 0.053\end{array}$ \\
\hline Daily feed intake (kg) & $\begin{array}{c}Q / Q \\
W t / Q \\
W t / W t\end{array}$ & $\begin{array}{l}2.430 \pm 0.069 \\
2.389 \pm 0.069 \\
2.411 \pm 0.071\end{array}$ & $\begin{array}{l}2.402 \pm 0.048 \\
2.366 \pm 0.041 \\
2.418 \pm 0.053\end{array}$ & $\begin{array}{l}2.228 \pm 0.047 \\
2.246 \pm 0.025 \\
2.311 \pm 0.040\end{array}$ \\
\hline Age at slaughter (days) & $\begin{array}{c}Q / Q \\
W t / Q \\
W t / W t\end{array}$ & $\begin{array}{l}170 \pm 5.607 \\
170 \pm 5.582 \\
173 \pm 5.784\end{array}$ & $\begin{array}{l}173 \pm 2.867 a b \\
177 \pm 2.464 b \\
178 \pm 3.171 a\end{array}$ & $\begin{array}{l}191 \pm 6.084 \mathrm{Ab} \\
180 \pm 3.305 \mathrm{bc} \\
174 \pm 5.160 \mathrm{Ac}\end{array}$ \\
\hline $\begin{array}{l}\text { Number of days on test } \\
\text { (days) }\end{array}$ & $\begin{array}{c}Q / Q \\
W t / Q \\
W t / W t\end{array}$ & $\begin{array}{l}81.8 \pm 2.402 \\
82.9 \pm 2.391 \\
82.9 \pm 2.478\end{array}$ & $\begin{array}{l}81.1 \pm 1.713 a \\
83.6 \pm 1.472 \\
83.9 \pm 1.895 a\end{array}$ & $\begin{array}{l}91.6 \pm 2.871 a \\
86.4 \pm 1.560 \\
84.3 \pm 2.435 a\end{array}$ \\
\hline
\end{tabular}

Values marked with the same letter differ statistically at $p \leq 0.05$ (abc) or $p \leq 0.01$ (ABC). 
Table 3: Association between VRTN polymorphism (g.20311_20312ins291) and carcass parameters in different pig breeds (LSM $\pm \mathrm{SE})$.

\begin{tabular}{|c|c|c|c|c|}
\hline Trait & Genotype & $\begin{array}{l}\text { Polish Landrace } \\
\quad(n=269)\end{array}$ & $\begin{array}{l}\text { Polish Large White } \\
(n=189)\end{array}$ & $\begin{array}{l}\text { Puławska } \\
(n=68)\end{array}$ \\
\hline Carcass yield (\%) & $\begin{array}{c}Q / Q \\
W t / Q \\
W t / W t\end{array}$ & $\begin{array}{l}77.9 \pm 0.619 \\
78.0 \pm 0.616 \\
78.3 \pm 0.638\end{array}$ & $\begin{array}{l}76.1 \pm 0.484 \mathrm{AB} \\
77.4 \pm 0.416 \mathrm{~B} \\
77.1 \pm 0.535 \mathrm{~A}\end{array}$ & $\begin{array}{l}75.1 \pm 0.884 \\
76.3 \pm 0.480 \\
75.5 \pm 0.750\end{array}$ \\
\hline Weight of loin without backfat and skin (kg) & $\begin{array}{l}Q / Q \\
W t / Q \\
W t / W t\end{array}$ & $\begin{array}{l}6.486 \pm 0.201 a \\
6.438 \pm 0.200 b \\
6.637 \pm 0.208 a b\end{array}$ & $\begin{array}{r}6.277 \pm 0.119 \\
6.333 \pm 0.102 \\
6.287 \pm 0.132\end{array}$ & $\begin{array}{l}5.918 \pm 0.191 \\
5.932 \pm 0.104 \\
5.634 \pm 0.162\end{array}$ \\
\hline Weight of ham without backfat and skin (kg) & $\begin{array}{l}Q / Q \\
W t / Q \\
W t / W t\end{array}$ & $\begin{array}{l}9.206 \pm 0.156 \\
9.308 \pm 0.155 \\
9.112 \pm 0.161\end{array}$ & $\begin{array}{l}9.048 \pm 0.106 \\
9.047 \pm 0.091 \\
9.227 \pm 0.118\end{array}$ & $\begin{array}{l}8.686 \pm 0.218 \\
9.106 \pm 0.119 \\
9.025 \pm 0.185\end{array}$ \\
\hline $\begin{array}{c}\text { Average backfat thickness from } 5 \\
\text { measurements }(\mathrm{cm})\end{array}$ & $\begin{array}{l}Q / Q \\
W t / Q \\
W t / W t\end{array}$ & $\begin{array}{l}1.344 \pm 0.085 a \\
1.371 \pm 0.084 b \\
1.489 \pm 0.087 a b\end{array}$ & $\begin{array}{l}1.322 \pm 0.050 \mathrm{~A} \\
1.355 \pm 0.043 \mathrm{~B} \\
1.488 \pm 0.055 \mathrm{AB}\end{array}$ & $\begin{array}{l}1.362 \pm 0.097 \mathrm{~A} \\
1.343 \pm 0.053 \mathrm{~B} \\
1.207 \pm 0.082 \mathrm{AB}\end{array}$ \\
\hline Loin eye width $(\mathrm{cm})$ & $\begin{array}{l}Q / Q \\
W t / Q \\
W t / W t\end{array}$ & $\begin{array}{l}10.42 \pm 0.205 \\
10.43 \pm 0.205 \\
10.63 \pm 0.212\end{array}$ & $\begin{array}{l}10.16 \pm 0.188 \\
10.22 \pm 0.162 \\
10.05 \pm 0.208\end{array}$ & $\begin{array}{l}10.12 \pm 0.272 b \\
10.10 \pm 0.198 a \\
10.23 \pm 0.231 a b\end{array}$ \\
\hline Loin eye length $(\mathrm{cm})$ & $\begin{array}{l}Q / Q \\
W t / Q \\
W t / W t\end{array}$ & $\begin{array}{l}6.98 \pm 0.189 \\
6.93 \pm 0.188 \\
7.02 \pm 0.195\end{array}$ & $\begin{array}{l}6.83 \pm 0.116 \\
6.86 \pm 0.089 \\
7.01 \pm 0.128\end{array}$ & $\begin{array}{l}6.98 \pm 0.182 \\
6.91 \pm 0.099 \\
6.68 \pm 0.155\end{array}$ \\
\hline Loin eye area $\left(\mathrm{cm}^{2}\right)$ & $\begin{array}{l}Q / Q \\
W t / Q \\
W t / W t\end{array}$ & $\begin{array}{l}55.0 \pm 1.445 \\
55.2 \pm 1.438 \\
56.3 \pm 1.491\end{array}$ & $\begin{array}{l}52.9 \pm 1.041 \\
53.6 \pm 0.895 \\
54.6 \pm 1.151\end{array}$ & $\begin{array}{l}50.6 \pm 1.911 a \\
50.3 \pm 1.038 b \\
51.7 \pm 1.621 a b\end{array}$ \\
\hline Lean meat percentage (\%) & $\begin{array}{c}Q / Q \\
W t / Q \\
W t / W t\end{array}$ & $\begin{array}{l}60.0 \pm 0.829 \\
60.3 \pm 0.825 \\
59.6 \pm 0.855\end{array}$ & $\begin{array}{l}61.3 \pm 0.564 \\
59.8 \pm 0.484 \\
60.8 \pm 0.623\end{array}$ & $\begin{array}{l}60.3 \pm 0.880 \\
60.7 \pm 0.478 \\
60.7 \pm 0.746\end{array}$ \\
\hline Weight of primary cuts (kg) & $\begin{array}{l}Q / Q \\
W t / Q \\
W t / W t\end{array}$ & $\begin{array}{l}24.4 \pm 0.353 \\
24.6 \pm 0.351 \\
24.5 \pm 0.364\end{array}$ & $\begin{array}{l}23.8 \pm 0.245 \\
23.8 \pm 0.210 \\
24.1 \pm 0.270\end{array}$ & $\begin{array}{l}22.8 \pm 0.509 a b \\
23.6 \pm 0.276 b \\
23.8 \pm 0.432 a b\end{array}$ \\
\hline
\end{tabular}

Values marked with the same letter differ statistically at $p \leq 0.05$ (abc) or $p \leq 0.01$ (ABC).

Among meat quality traits the GLM procedure showed the significant association of VRTN polymorphism and intramuscular fat content, meat colour and $\mathrm{pH}$ measured $24 \mathrm{~h}$ after slaughter (Table 4). Hirose et al. (2013) shown that IMF in longissimus muscle was significantly associated with the VRTN genotypes in Duroc pigs. The mean IMF of pigs with $W t / W t$ genotype was greater than that of animals with the $W t / Q$ and $Q / Q$ genotypes ( $\mathrm{p} \leq 0.05$ ). We observed the same tendency in our study. In Polish Large White and Puławska pigs with $W t / W t$ genotype were characterized by highest value of intramuscular fat content. It was also observed in Polish Landrace but not confirmed by statistical test. Other studies, however did not detect significant associations between VRTN variants and intramuscular fat content (Nakado et al., 2015; Yang at al., 2016). Hirose et al. (2014) also suggested that VRTN may independently influence growth rate and fat deposition. It is good visible when take into consideration test daily gain and lifetime daily gain from the first group of traits and average backfat thickness from 5 measurements and intramuscular fat content from the second. In our study, highest gains were noticed in commercial pigs with $Q / Q$ genotype, however highest fat deposition were observed in animals with $W t / W t$ genotype. As mentioned earlier VRTN genotypes were also related with meat colour - yellowness and $\mathrm{pH} 45$ measured in $\mathrm{m}$. semimembranosus but they were a single cases involving one breed.

Interesting results were obtained for parameters describing $m$. longissimus lumborum (loin) and $m$. semimembranosus (ham) texture in different pig breeds. (Table 5 and 6). We found significant association of VRTN polymorphism and toughness, firmness, cohesiveness 
and chewiness in $m$. longissimus lumborum. For $m$. semimembranosus significant differences were observed such features as toughness, firmness, and chewiness. Toughness was measured in raw muscles as well as in cooked. In cooked loin and ham of Polish Large White, highest values of this parameter were observed in animals with $Q / Q$ genotype $(\mathrm{p} \leq 0.01, \mathrm{p} \leq 0.05)$. In case of raw muscle the same tendency was observed but in other breed - Puławska ( $\mathrm{p} \leq 0.01, \mathrm{p} \leq 0.05) . Q / Q$ genotype was also associated with highest chewiness of ham in all breeds $(p \leq 0.05)$. Highest cohesiveness of loin, however were characterized pigs with heterozygous genotype $W t / Q(\mathrm{p} \leq 0.01, \mathrm{p} \leq 0.05)$. In our study, we analyzed for the first time VRTN variants in relation to texture parameters of two economically important muscles. Earlier report showed that other genes were associated with these traits - triglyceride transfer protein $(M T P)$, calpastatin (CAST) and paraoxonase 3 (PON3) (Ropka-Molik et al., 2014; 2016; Hur et al., 2017). When we take into consideration all analyzed traits in Polish Large White pigs, it is visible that animals with $Q / Q$ genotype are characterized by highest average daily gain, however low intramuscular fat content and high toughness. These two groups of traits are in antagonism, because $Q / Q$ pigs have high productivity and low meat quality. Average daily gain and intramuscular fat content are much important economically traits, thus VRTN gene cannot be used as genetic marker in this breed. It could be used, however in the case of design specialized pig lines targeting individual utility groups (growth rate, feed efficiency, meat quality)

Table 4: Association between VRTN polymorphism (g.20311_20312ins291) and meat quality traits in different pig breeds (LSM $\pm \mathrm{SE})$.

\begin{tabular}{|c|c|c|c|c|}
\hline Trait & Genotype & $\begin{array}{l}\text { Polish Landrace } \\
\quad(n=269)\end{array}$ & $\begin{array}{l}\text { Polish Large White } \\
(n=189)\end{array}$ & $\begin{array}{c}\text { Puławska } \\
(n=68)\end{array}$ \\
\hline Intramuscular fat content (\%) & $\begin{array}{l}Q / Q \\
W t / Q \\
W t / W t\end{array}$ & $\begin{array}{l}1.148 \pm 0.043 \\
1.171 \pm 0.042 \\
1.184 \pm 0.045\end{array}$ & $\begin{array}{l}1.174 \pm 0.062 a \\
1.209 \pm 0.054 \\
1.231 \pm 0.067 a\end{array}$ & $\begin{array}{l}1.133 \pm 0.046 a \\
1.182 \pm 0.023 \\
1.245 \pm 0.036 a\end{array}$ \\
\hline Meat colour - luminosity $\left(L^{*}\right)$ & $\begin{array}{l}Q / Q \\
W t / Q \\
W t / W t\end{array}$ & $\begin{array}{l}49.7 \pm 0.797 \\
49.6 \pm 0.793 \\
49.7 \pm 0.824\end{array}$ & $\begin{array}{l}52.8 \pm 0.393 \\
52.9 \pm 0.336 \\
52.9 \pm 0.433\end{array}$ & $\begin{array}{l}53.7 \pm 0.585 \\
53.8 \pm 0.318 \\
54.3 \pm 0.496\end{array}$ \\
\hline Meat colour - redness $\left(a^{*}\right)$ & $\begin{array}{c}Q / Q \\
W t / Q \\
W t / W t\end{array}$ & $\begin{array}{l}18.43 \pm 0.545 \\
18.33 \pm 0.542 \\
18.56 \pm 0.563\end{array}$ & $\begin{array}{l}17.9 \pm 0.267 \\
17.9 \pm 0.228 \\
17.9 \pm 0.294\end{array}$ & $\begin{array}{l}16.77 \pm 0.325 \\
16.71 \pm 0.176 \\
17.02 \pm 0.275\end{array}$ \\
\hline Meat colour - yellowness $\left(b^{*}\right)$ & $\begin{array}{l}Q / Q \\
W t / Q \\
W t / W t\end{array}$ & $\begin{array}{l}5.411 \pm 0.443 \\
5.191 \pm 0.441 \\
4.771 \pm 0.458\end{array}$ & $\begin{array}{l}5.072 \pm 0.225 \\
5.430 \pm 0.192 \\
5.131 \pm 0.247\end{array}$ & $\begin{array}{l}2.031 \pm 0.189 a \\
2.337 \pm 0.103 \\
2.446 \pm 0.161 a\end{array}$ \\
\hline $\begin{array}{c}\mathrm{pH} 45 \\
\text { (m. longissimus dorsi) }\end{array}$ & $\begin{array}{l}Q / Q \\
W t / Q \\
W t / W t\end{array}$ & $\begin{array}{l}6.218 \pm 0.057 \\
6.246 \pm 0.057 \\
6.235 \pm 0.059\end{array}$ & $\begin{array}{l}6.266 \pm 0.041 \\
6.259 \pm 0.035 \\
6.306 \pm 0.045\end{array}$ & $\begin{array}{l}6.330 \pm 0.048 \\
6.277 \pm 0.026 \\
6.265 \pm 0.041\end{array}$ \\
\hline $\begin{array}{c}\mathrm{pH} 24 \\
\text { (m. longissimus dorsi) }\end{array}$ & $\begin{array}{l}Q / Q \\
W t / Q \\
W t / W t\end{array}$ & $\begin{array}{l}5.540 \pm 0.031 \\
5.554 \pm 0.030 \\
5.519 \pm 0.032\end{array}$ & $\begin{array}{l}5.532 \pm 0.018 \\
5.532 \pm 0.016 \\
5.572 \pm 0.020\end{array}$ & $\begin{array}{l}5.668 \pm 0.020 \\
5.611 \pm 0.011 \\
5.639 \pm 0.017\end{array}$ \\
\hline $\begin{array}{c}\mathrm{pH} 45 \\
\text { (m. semimembranosus) }\end{array}$ & $\begin{array}{l}Q / Q \\
W t / Q \\
W t / W t\end{array}$ & $\begin{array}{l}6.287 \pm 0.048 \\
6.285 \pm 0.048 \\
6.215 \pm 0.049\end{array}$ & $\begin{array}{l}6.374 \pm 0.038 \\
6.382 \pm 0.032 \\
6.419 \pm 0.042\end{array}$ & $\begin{array}{l}6.322 \pm 0.041 \\
6.253 \pm 0.022 \\
6.250 \pm 0.035\end{array}$ \\
\hline $\begin{array}{c}\mathrm{pH} 24 \\
\text { (m. semimembranosus) }\end{array}$ & $\begin{array}{l}Q / Q \\
W t / Q \\
W t / W t\end{array}$ & $\begin{array}{l}5.643 \pm 0.030 \\
5.656 \pm 0.030 \\
5.648 \pm 0.031\end{array}$ & $\begin{array}{l}5.634 \pm 0.023 a \\
5.629 \pm 0.020 b \\
5.693 \pm 0.025 a b\end{array}$ & $\begin{array}{l}5.647 \pm 0.042 \\
5.639 \pm 0.023 \\
5.665 \pm 0.036\end{array}$ \\
\hline Water holding-capacity & $\begin{array}{l}Q / Q \\
W t / Q \\
W t / W t\end{array}$ & $\begin{array}{l}34.3 \pm 1.784 \\
33.1 \pm 1.772 \\
34.4 \pm 1.835\end{array}$ & $\begin{array}{l}32.9 \pm 1.251 \\
33.0 \pm 1.102 \\
31.8 \pm 1.355\end{array}$ & $\begin{array}{r}33.10 \pm 0.011 \\
34.6 \pm 1.093 \\
33.2 \pm 1.706\end{array}$ \\
\hline
\end{tabular}

pH45, pH24 - pH measured 45 min and $24 \mathrm{~h}$ after slaughter respectively; values in the same row marked with the same letter differ statistically at $\mathrm{p} \leq 0.05$. 
Table 5: Association between VRTN polymorphism (g.20311_20312ins291) and $m$. longissimus lumborum texture parameters in different pig breeds (LSM $\pm \mathrm{SE}$ ).

\begin{tabular}{ccccc}
\hline Trait & Genotype & $\begin{array}{c}\text { Polish Landrace } \\
(\mathrm{n}=269)\end{array}$ & $\begin{array}{c}\text { Polish Large White } \\
(\mathrm{n}=189)\end{array}$ & $\begin{array}{c}\text { Puławska } \\
(\mathrm{n}=68)\end{array}$ \\
\hline \multirow{3}{*}{ Firmness $(\mathrm{r})$} & $Q / Q$ & $30.3 \pm 3.278$ & $31.6 \pm 2.027$ & $20.93 \pm 3.057$ \\
& $W t / Q$ & $30.9 \pm 3.253$ & $32.8 \pm 1.779$ & $18.54 \pm 1.517$ \\
& $W t / W t$ & $28.3 \pm 3.368$ & $28.2 \pm 2.210$ & $17.34 \pm 2.482$ \\
Toughness $(\mathrm{r})$ & $Q / Q$ & $79.0 \pm 9.112$ & $86.9 \pm 5.912$ & $68.8 \pm 9.59 \mathrm{AB}$ \\
& $W t / Q$ & $86.3 \pm 9.044$ & $89.9 \pm 5.189$ & $49.9 \pm 4.76 \mathrm{~B}$ \\
& $W t / W t$ & $86.2 \pm 9.364$ & $87.2 \pm 6.448$ & $49.2 \pm 7.79 \mathrm{~A}$ \\
Firmness & $Q / Q$ & $98.1 \pm 6.161 \mathrm{~b}$ & $93.3 \pm 4.417$ & $73.9 \pm 5.969$ \\
& $W t / Q$ & $93.6 \pm 6.115 \mathrm{a}$ & $93.1 \pm 3.877$ & $74.5 \pm 2.962$ \\
& $W t / W t$ & $91.3 \pm 6.331 \mathrm{ab}$ & $91.5 \pm 4.817$ & $73.7 \pm 4.846$ \\
Toughness & $Q / Q$ & $223 \pm 15.46$ & $230 \pm 12.36 \mathrm{ab}$ & $178 \pm 15.87$ \\
& $W t / Q$ & $221 \pm 15.35$ & $221 \pm 10.85 \mathrm{~b}$ & $174 \pm 7.878$ \\
& $W t / W t$ & $221 \pm 15.89$ & $221 \pm 13.48 \mathrm{a}$ & $174 \pm 12.89$ \\
Hardness & $Q / Q$ & $9.786 \pm 1.048$ & $11.46 \pm 0.801$ & $5.068 \pm 1.198$ \\
& $W t / Q$ & $9.375 \pm 1.040$ & $11.38 \pm 0.703$ & $7.312 \pm 0.595$ \\
& $W t / W t$ & $9.211 \pm 1.077$ & $11.19 \pm 0.873$ & $6.436 \pm 0.973$ \\
Springiness & $Q / Q$ & $0.698 \pm 0.018$ & $0.722 \pm 0.013$ & $0.644 \pm 0.021$ \\
& $W t / Q$ & $0.703 \pm 0.018$ & $0.736 \pm 0.011$ & $0.695 \pm 0.010$ \\
& $W t / W t$ & $0.679 \pm 0.019$ & $0.726 \pm 0.014$ & $0.669 \pm 0.017$ \\
Cohesiveness & $Q / Q$ & $0.660 \pm 0.017 \mathrm{a}$ & $0.685 \pm 0.012 \mathrm{a}$ & $0.601 \pm 0.019$ \\
& $W t / Q$ & $0.663 \pm 0.017 \mathrm{~b}$ & $0.688 \pm 0.010 \mathrm{~b}$ & $0.638 \pm 0.010$ \\
& $W t / W t$ & $0.636 \pm 0.017 \mathrm{ab}$ & $0.665 \pm 0.013 \mathrm{ab}$ & $0.604 \pm 0.016$ \\
& $Q / Q$ & $4.732 \pm 0.517 \mathrm{ac}$ & $5.490 \pm 0.378$ & $3.150 \pm 0.605 \mathrm{a}$ \\
Chewiness & $W t / Q$ & $4.459 \pm 0.513 \mathrm{bc}$ & $5.521 \pm 0.332$ & $3.406 \pm 0.300 \mathrm{~b}$ \\
& $W t / W t$ & $4.163 \pm 0.531 \mathrm{ab}$ & $5.579 \pm 0.412$ & $2.652 \pm 0.491 \mathrm{ab}$ \\
& $W / Q$ & $0.289 \pm 0.010$ & $0.295 \pm 0.007$ & $0.256 \pm 0.013$ \\
& $W t / W t$ & $0.291 \pm 0.010$ & $0.307 \pm 0.006$ & $0.272 \pm 0.006$ \\
Resilience & $0.276 \pm 0.010$ & $0.295 \pm 0.008$ & $0.255 \pm 0.010$ \\
& & & &
\end{tabular}

$r$ - raw tissue; values marked with the same letter differ statistically at $p \leq 0.05$ (abc) or $p \leq 0.01$ (ABC).

Table 6: Association between VRTN polymorphism (g.20311_20312ins291) and m. semimembranosus texture parameters in different pig breeds (LSM $\pm \mathrm{SE}$ ).

\begin{tabular}{ccccc}
\hline Trait & Genotype & $\begin{array}{c}\text { Polish Landrace } \\
(\mathrm{n}=269)\end{array}$ & $\begin{array}{c}\text { Polish Large White } \\
(\mathrm{n}=189)\end{array}$ & $\begin{array}{c}\text { Puławska } \\
(\mathrm{n}=68)\end{array}$ \\
\hline \multirow{3}{*}{ Firmness $(\mathrm{r})$} & $Q / Q$ & $24.5 \pm 1.947$ & $26.6 \pm 1.743$ & $23.4 \pm 1.681$ \\
& $W t / Q$ & $25.5 \pm 1.951$ & $26.8 \pm 1.458$ & $23.9 \pm 0.918$ \\
& $W t / W t$ & $24.4 \pm 2.035$ & $27.9 \pm 1.838$ & $21.6 \pm 1.426$ \\
\multirow{3}{*}{ Toughness $(\mathrm{r})$} & $Q / Q$ & $78.5 \pm 6.591$ & $79.6 \pm 6.053$ & $68.5 \pm 5.253 \mathrm{a}$ \\
& $W t / Q$ & $78.5 \pm 6.604$ & $80.0 \pm 5.063$ & $68.2 \pm 2.869 \mathrm{~b}$ \\
& $W t / W t$ & $77.9 \pm 6.890$ & $79.0 \pm 6.383$ & $60.7 \pm 4.456 \mathrm{ab}$ \\
Firmness & $Q / Q$ & $86.0 \pm 6.405 \mathrm{a}$ & $96.0 \pm 6.342 \mathrm{a}$ & $82.3 \pm 7.107$ \\
& $W t / Q$ & $87.2 \pm 6.417 \mathrm{~b}$ & $94.2 \pm 5.305 \mathrm{~b}$ & $82.4 \pm 3.882$ \\
& $W t / W t$ & $91.7 \pm 6.695 \mathrm{ab}$ & $83.6 \pm 6.688 \mathrm{ab}$ & $87.9 \pm 6.029$ \\
& $Q / Q$ & $227 \pm 14.81 \mathrm{~b}$ & $246 \pm 16.66 \mathrm{Ac}$ & $198 \pm 14.98$ \\
Toughness & $W t / Q$ & $226 \pm 14.84 \mathrm{a}$ & $228 \pm 13.94 \mathrm{Bc}$ & $195 \pm 8.182$ \\
& $W t / W t$ & $231 \pm 15.48 \mathrm{ab}$ & $205 \pm 17.57 \mathrm{AB}$ & $201 \pm 12.71$ \\
\hline
\end{tabular}


Table 6: Continuation...

\begin{tabular}{|c|c|c|c|c|}
\hline Trait & Genotype & $\begin{array}{l}\text { Polish Landrace } \\
\quad(n=269)\end{array}$ & $\begin{array}{l}\text { Polish Large White } \\
(n=189)\end{array}$ & $\begin{array}{l}\text { Puławska } \\
(\mathrm{n}=68)\end{array}$ \\
\hline Hardness & $\begin{array}{c}Q / Q \\
W t / Q \\
W t / W t\end{array}$ & $\begin{array}{r}28.43 \pm 2.7 \\
27.6 \pm 2.8 \\
24.7 \pm 2.7\end{array}$ & $\begin{array}{l}11.34 \pm 1.126 \\
11.62 \pm 0.942 \\
9.541 \pm 1.187\end{array}$ & $\begin{array}{l}11.38 \pm 1.239 \\
9.568 \pm 0.676 \\
10.16 \pm 1.051\end{array}$ \\
\hline Springiness & $\begin{array}{c}Q / Q \\
W t / Q \\
W t / W t\end{array}$ & $\begin{array}{l}0.771 \pm 0.026 \\
0.777 \pm 0.026 \\
0.769 \pm 0.027\end{array}$ & $\begin{array}{l}0.771 \pm 0.025 \\
0.766 \pm 0.021 \\
0.779 \pm 0.027\end{array}$ & $\begin{array}{l}0.684 \pm 0.024 \\
0.727 \pm 0.013 \\
0.727 \pm 0.021\end{array}$ \\
\hline Cohesiveness & $\begin{array}{c}Q / Q \\
W t / Q \\
W t / W t\end{array}$ & $\begin{array}{l}0.689 \pm 0.022 \\
0.684 \pm 0.022 \\
0.673 \pm 0.022\end{array}$ & $\begin{array}{l}0.721 \pm 0.124 \\
0.740 \pm 0.104 \\
0.926 \pm 0.131\end{array}$ & $\begin{array}{l}0.595 \pm 0.024 \\
0.639 \pm 0.013 \\
0.598 \pm 0.021\end{array}$ \\
\hline Chewiness & $\begin{array}{c}Q / Q \\
W t / Q \\
W t / W t\end{array}$ & $\begin{array}{l}5.376 \pm 0.704 a \\
4.872 \pm 0.705 \\
4.636 \pm 0.736 a\end{array}$ & $\begin{array}{l}5.943 \pm 0.484 a \\
5.931 \pm 0.579 b \\
4.865 \pm 0.611 a b\end{array}$ & $\begin{array}{l}4.710 \pm 0.706 \\
4.580 \pm 0.385 \\
4.689 \pm 0.599\end{array}$ \\
\hline Resilience & $\begin{array}{c}Q / Q \\
W t / Q \\
W t / W t\end{array}$ & $\begin{array}{l}0.303 \pm 0.012 \\
0.297 \pm 0.012 \\
0.296 \pm 0.012\end{array}$ & $\begin{array}{l}0.294 \pm 0.010 \\
0.295 \pm 0.008 \\
0.300 \pm 0.010\end{array}$ & $\begin{array}{l}0.244 \pm 0.013 \\
0.264 \pm 0.007 \\
0.264 \pm 0.007\end{array}$ \\
\hline
\end{tabular}

$r$ - raw tissue; values marked with the same letter differ statistically at $p \leq 0.05$.

\section{CONCLUSIONS}

The present study showed that VRTN polymorphism is associated with several economically important traits. They including carcass yield, intramuscular fat content, chewiness of ham and cohesiveness of loin. Among them, intramuscular fat content is very important, because is a polygenic trait that affects other meat quality traits such as flavour, drip loss and shear force. In all analyzed breeds, $Q / Q$ genotype was associated with lowest carcass yield, and highest ham chewiness, $W t / W t$ with highest intramuscular fat content, however $Q / W t$ with highest loin cohesiveness. In the future, other populations should be studied to clarify the effects of VRTN gene on porcine productive traits.

\section{REFERENCES}

ANDERSEN, H. J. et al. Feeding and meat quality - A future approach. Meat Science, 70:543-554, 2005.

BABICZ, M. et al. The analysis of changes in the profitability of pig production of Polish Landrace breed and the Pulawska breed on a family farm in the years 2010-2012. Annales Universitatis Mariae Curie-Skłodowska, sectio H, 32:17-24, 2014.

BERGE, S. Genetical researches on the number of vertebrae in the pig. Journal of Animal Science, 7:233-238, 1948.

BURGOS, C. et al. Allelic frequencies of NR6A1 and VRTN, two genes that affect vertebrae number in diverse pig breeds: A study of the effects of the VRTN insertion on phenotypic traits of a Duroc $\times$ Landrace-Large White cross. Meat Science, 100:150-155, 2015.

FAN, Y. et al. A further look at porcine chromosome 7 reveals VRTN variants associated with vertebral number in Chinese and Western pigs. PLoS ONE, 8:e62534, 2013.

FONTANESI, L. et al. Investigation of a short interspersed nuclear element polymorphic site in the porcine vertnin gene: Allele frequencies and association study with meat quality, carcass and production traits in Italian Large White pigs. Italian Journal of Animal Science, 3:60-65, 2014.

FREDEEN, H. T.; NEWMAN, J. A. Rib and vertebral numbers in swine. II. Genetic aspects. Canadian Journal of Animal Science, 42:240-251, 1962.

HAMM, R. Functional properties of the myofibrilar system and their measurement. In: BECHTEL, P. J. Muscle as food. London: Academic Press Inc, 1986, p.135-199.

HIROSE, K. et al. Evaluation of effects of multiple candidate genes (LEP, LEPR, MC4R, PIK3C3 and VRTN) on production traits in Duroc pigs. Journal of Animal Science, 85:198-206, 2014.

HIROSE, K. et al. Association of swine vertnin (VRTN) gene with production traits in Duroc pigs improved using a closed nucleus breeding system. Journal of Animal Science, 84:213-221, 2013.

HUR,J.W. et al. A non-synonymous single nucleotide polymorphism in the paraoxonase 3 gene regulates meat quality in Berkshire pigs. Animal Production Science, AN16573, 2017. 
LEE, T. et al. Genome-wide association study of integrated meat quality-related traits of the Duroc pig breed. AsianAustralasian Journal of Animal Science, 27: 303-309, 2014.

MIKAWA, S. et al. Identification of a second gene associated with variation in vertebral number in domestic pigs. BMC Genetics, 12(5):1-13, 2011.

NAKANO, $\mathrm{H}$. et al. Effect of VRTN gene polymorphisms on Duroc pig production and carcass traits, and their genetic relationships. Journal of Animal Science, 86,125-131, 2015.

OCZKOWICZ, M. et al. Effect of IGF2 intron3-g.3072G>A on intramuscular fat (IMF) content in pigs raised in Poland. Livestock Science, 149:301-304, 2012.

ROPKA-MOLIK, K. et al. Association of calpastatin gene polymorphisms and meat quality traits in pig. Meat Science, 97:143-150, 2014.
ROPKA-MOLIK, K. et al. Association of gene coding for microsomal triglyceride Transfer Protein (MTP) and Meat texture characteristic in pig. Annals of Animal Science, 16:721-729, 2016.

SUN, F. et al. Common evolutionary trends for SINE RNA structures. Trends Genet., 23:26-33, 2006.

TYRA, M.; ŻAK, G. Analysis of relationships between fattening and slaughter performance of pigs and the level of intramuscular fat (IMF) in longissimus lumborum muscle.

Annals of Animal Science, 12:169-178, 2012.

YANG, J. et al. Possible introgression of the VRTN mutation increasing vertebral number, carcass length and teat number from Chinese pigs into European. Scientific Reports, 6:19240, 2016. 